\title{
Prayers for the departed: A white elephant in the hymnal of the Evangelical Lutheran Church in Tanzania
}

\begin{tabular}{|c|c|}
\hline \multicolumn{2}{|c|}{$\begin{array}{l}\text { Authors: } \\
\text { Kim S. Groop } \\
\text { Nehemia Moshi } \\
\text { (D) }\end{array}$} \\
\hline \multicolumn{2}{|c|}{$\begin{array}{l}\text { Affiliations: } \\
{ }^{1} \text { Faculty of Arts, Psychology } \\
\text { and Theology, Åbo Akademi } \\
\text { University, Finland }\end{array}$} \\
\hline \multicolumn{2}{|c|}{$\begin{array}{l}{ }^{2} \text { Faculty of Theology, Tumaini } \\
\text { University Makumira, Tanzania }\end{array}$} \\
\hline \multicolumn{2}{|c|}{$\begin{array}{l}{ }^{3} \text { Department of Science of } \\
\text { Religion and Missiology, } \\
\text { Faculty of Theology and } \\
\text { Religion, University of } \\
\text { Pretoria, South Africa }\end{array}$} \\
\hline \multicolumn{2}{|c|}{$\begin{array}{l}\text { Research Project Registration: } \\
\text { Project Leader: N. Niemandt } \\
\text { Project Number: } 04317734\end{array}$} \\
\hline \multicolumn{2}{|c|}{$\begin{array}{l}\text { This research is part of the } \\
\text { research project, 'Mission } \\
\text { from the margins: Missiolog } \\
\text { and human dignity', directed } \\
\text { by Prof. Dr Nelus Niemandt, } \\
\text { Department of Science of } \\
\text { Religion and Missiology, } \\
\text { Faculty of Theology, } \\
\text { University of Pretoria. }\end{array}$} \\
\hline \multicolumn{2}{|c|}{$\begin{array}{l}\text { Corresponding auth } \\
\text { Kim Groop, } \\
\text { kim.groop@abo.fi }\end{array}$} \\
\hline \multicolumn{2}{|c|}{$\begin{array}{l}\text { Received: } 18 \text { June } 2018 \\
\text { Accepted: } 10 \text { Nov. } 2018 \\
\text { Published: } 14 \text { Feb. } 2019\end{array}$} \\
\hline \multicolumn{2}{|c|}{$\begin{array}{l}\text { How to cite this article: } \\
\text { Groop, K.S., \& Moshi, N., } \\
\text { 2019, 'Prayers for the } \\
\text { departed: A white elephant } \\
\text { in the hymnal of the } \\
\text { Evangelical Lutheran Church } \\
\text { in Tanzania', HTS Teologiese } \\
\text { Studies/Theological Studies } \\
75(1), \text { a5162. https://doi. } \\
\text { org/10.4102/hts.v75i1.5162 }\end{array}$} \\
\hline \multicolumn{2}{|l|}{ Read online: } \\
\hline 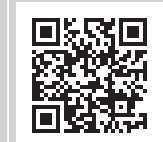 & $\begin{array}{l}\text { Scan this QR } \\
\text { code with your } \\
\text { smart phone or } \\
\text { mobile device } \\
\text { to read online. }\end{array}$ \\
\hline
\end{tabular}

The aim of this article is to study the general and contextual issues related to prayers for the departed with a focus on the Evangelical Lutheran Church in Tanzania (ELCT). In 2012, the ELCT published a new hymnal, which included a number of prayers for those mourning their deceased friends and relatives, as well as prayers for the deceased individuals themselves. As a result of considerable criticism, this hymnal was replaced by a new edition in 2017, in which the prayers for the departed were omitted. The article further scrutinises the historical and theological aspects of praying for the departed in Lutheranism. It studies examples of prayers for the dead in Lutheran churches in two other countries, Finland and Sweden, and relates these to the situation in the ELCT.

\section{Introduction}

Prayer in relation to death and the departed has constituted a central element in the religious practice of Christianity since the early church. Typically, the saints would be counted upon as mediators between the praying Christians and God. However, earlier, ordinary Christians who had passed on were also included in the prayers. The boundary between saint and ordinary Christian was at times unclear (Brown 2000:43-45; Dal Santo 2011:129-130, 140-141; Heidemann 2011:188). Nonetheless, as the Catholic Church almost entirely embraced Europe and its citizens during the medieval era, most of the dead ones prayed for or to would be either saints or ordinary Christians. Praying for departed non-Christians probably occurred at times, not least in geographical perimeters where the Christian faith coexisted with other faith systems.

In terms of organised praying for the dead (e.g. prayers in church settings or published in hymnals or church handbooks of various kinds), this practice has become more common in recent times. For instance, in countries with increased secularisation, non-Christians, after their death, have often been included in organised church prayers - often when their relatives have insisted that the one being buried be given a Christian burial although he or she was not a Christian. ${ }^{1}$ Moreover, in the wake of increased plurality and religious intermingling, many Christians and churches worldwide have deviated from their own church tradition or included other traditions in their own. Hence, 'old' customs have given way to 'new' ones - including praying for, and communicating with, those who have died. ${ }^{2}$

In the Evangelical Lutheran Church in Tanzania (ELCT), public prayers for the departed have generally been rare or unheard of. However, in the Tanzanian Lutheran Church organised praying for the dead has also increased. This trend is manifest in the development of the ELCT hymnal, which constitutes a key tool for the worship life of ELCT members. The hymnal has been produced in several versions. These versions have seen a progressive increase in the number of hymns. However, of significance to this article is the increase in liturgical material, special orders and prayers. For instance, the pre-WWI edition (c. 1914) of the hymnal Nyimbo za Kikristo [Christian Hymns] ${ }^{3}$ consisted of hymns and a few liturgies. Later editions, such as 1.As a recent example, from England, Stephen Hawking was given a Christian funeral though he considered himself and was regarded as a stern atheist. See, for instance, Daily Mail, 30.3.2018.

2.For instance, many Lutheran churches worldwide have in recent times introduced elements from Catholic and Greek Orthodox settings, such as icons, increased use of the sign of the cross, pilgrimages and lighting of candles in the churches while praying for alive and departed friends and relatives.

3.The year of publication of the hymnal is not indicated but as can be seen from the discussion below, around 1914 is a reasonable guess. Though the ELCT, established in 1963, was not present at this time, this version was of importance because the ELCT adopted an edited version of Nyimbo za Kikristo [Christian Hymns] as its hymnal. 
Mwimbieni Bwana (1988) [Sing to the Lord] and Tumwabudu Mungu Wetu (2012) [Let Us Worship Our God], included an order of worship, prayers for special occasions, the creeds and so on. Some of the contents of the 2012 edition of the ELCT hymnal raised eyebrows among ELCT members, notably pages $607-612$, containing special prayers for the departed. The critics questioned this as a deviation from Lutheran theology. The issues mouldered on for some time and finally erupted during the pastors' assembly held 24-29 September 2016 in the capital city of Dodoma. Some pastors asked why these prayers were in the hymnal. One bishop, who was a member of the committee that compiled the hymnal, gave some explanations. He pointed out that members of the committee had been divided as to whether or not the prayers should be included. Some had resisted and some had considered the prayers worthwhile incorporating in the book. When analysed, the bishop's explanation suggests that there were tensions even among the members of the committee that had inserted the prayers. Furthermore, in the bishop's conclusion of the matter, he pointed to the likely omission of the prayers from the hymnal in the future. ${ }^{4}$

In 2017, the ELCT printed a revised edition of the 2012 hymnal with the prayers omitted. The ambivalence reflected in the insertion of the prayers and their withdrawal shortly afterwards raises questions: What were the reasons behind the ELCT's decision to include the prayers in its hymnal in the first place? What is the Lutheran doctrinal position regarding prayer for the departed? What are the influences behind the disapproval of the prayers by ELCT members?

The aim of this article is to study the general and contextual issues related to prayers for the departed. The article scrutinises the historical and theological aspects of the phenomenon in early Lutheranism. It further studies examples of prayers for the dead in two Lutheran 'sister churches' in Finland and Sweden - from which missionaries have been dispatched to Tanzania since the 1940s - and it relates these examples to the current situation in the ELCT. The article does not intend to be prescriptive. Nor does it make any active attempts at solving the issue in the ELCT. Rather, it is an attempt at a passionate and sympathetic analysis of the situation in the ELCT regarding these prayers, and it is our hope to be able to provide some historical and theological insights that may be of help. The main sources consist of hymnals and worship books. Certain writings by Martin Luther and Philipp Melanchthon were also consulted. Finally, interviews were conducted with select theologians who possess valuable information about the recent hymnal development in Tanzania. ${ }^{5}$

4.Nehemia Moshi participated in this meeting. The reflections above are based on his notes.

5.It has not been our intention to interview a great number of people with the aim of studying the church members' opinions about praying for the dead in the ELCT. This would demand a separate study. Rather we have restricted ourselves to a few select interviews in order to obtain specific information about the relation between the church members and prayers for the dead in the hymnals.

\section{Historical development of the hymnal in the Evangelical Lutheran Church in Tanzania}

Along with prayers, hymns play an important role in Christian circles. The singing of hymns is commonly regarded as praying, praising and proclaiming and, at least in Protestantism, the church hymnals - consisting of hymns, but often also of prayers and orders of service - have constituted an important tool in worship life since the late 17 th and early 18 th centuries.

The ELCT came into existence in 1963, following the merging of the seven Lutheran churches in Tanganyika. These churches were established by the efforts of different mission societies from Europe and the US (Smedjebacka 1973:309310). In the history of these seven churches, several hymnals have been used. These hymnbooks largely reflect the European and US founding churches and mission societies. ${ }^{6}$ According to Sigvard Von Sicard, the first Lutheran hymnal in the Swahili language was published in 1894. It was the work of the so-called Universities' Mission to Central Africa and was entitled Nyimbo Kisuaheli kwa Dini [Kiswahili Religious Songs]. In 1900, the Evangelical Mission Society for German East Africa printed an enlarged edition of this hymnal under a new name, Nyimbo za Dini zilizotumika katika Makanisa ya Pwani na Uzaramo [Religious Songs Used in the Coastal and Uzaramo Churches], and in 1908 a new edition was published under the name Kitabu cha Nyimbo [A Hymn Book] (Evangelische Missionsgesellschaft für Ostafrika 1908; Von Sicard 1970:182-183). This book had 93 hymns and can be considered the prototype of the original versions of what would constitute the ELCT hymnal. ${ }^{7}$ A similar early development took place in the Bethel Mission field. Gustav Menzel writes that the Bethel Mission issued its first hymnal in 1902. This songbook contained 50 hymns. When it was reprinted in 1907, it had 102 hymns (Menzel 1986:144). It was probably in 1914 that the Bethel Mission hymnal was given the name Nyimbo za Kikristo [Christian Hymns]. This edition had 142 hymns, in addition to an order of Sunday worship service and some prayers (Bethel Mission c. 1914), ${ }^{8}$ and in 1927 Nyimbo za Kikristo had 168 hymns (Bethel-Bielefeld Mission 1927).

The development of the ELCT hymnal cannot be separated from the efforts made to form a unified Lutheran church in Tanganyika. In fact, it is hard to speak about unified Lutheranism in Tanganyika, in the strict sense of the term, before the latter half of the 1930s. The efforts for unity culminated in the founding of the Mission Church Federation

6.For instance, Gustav Menzel quotes a passage from the first printed hymnal of the Bethel Mission (1908), according to which this hymnal 'contains the pearls of our German hymns, next to the most beautiful of our spiritual folk songs'. See Menzel (1986:145)

7.The introductory notes to the Nyimbo za Kikristo and the layout of the hymns bear much resemblance to the 1908 hymnal. Whether or not this has to do with the printers - Vuga Press, which was also located in Usambara - is beyond the coverage printers - Vuga
of this article.

8.Nyimbo za Kikristo (n.d.) - The fixing of the date is based on German missionary activity, which suffered turmoil with the onset of the First World War. 
(MCF) in 1937 (Smedjebacka 1973:55). It was during this time, when the Lutheran churches in Tanganyika were forging their unity, that another version of Nyimbo za Kikristo was published. The 1936 version of Nyimbo za Kikristo was an amplification of the previous hymnals (Bethel Mission 1936). The authors of the foreword in the 1954 print of the hymnal indicate that three versions of this hymnal had been printed before the year 1945 - probably 1914, 1927 and 1936. The Leipzig missionary Paul Rother's contribution is also acknowledged (Makanisa ya Kilutheri ya Tanganyika 1954). Rother was the first president of the MCF (Smedjebacka 1973:55). Although the hymnal was still issued by the Bethel Mission, the acknowledgement of Rother can be taken as a gesture of unity among Lutherans in Tanganyika in the mid-war period.

The first hymnal by the Lutheran churches in Tanganyika (Makanisa ya Kilutheri Tanganyika) was named Nyimbo za Kikristo after its early 20th-centuryBethel Mission predecessors. It was published around the year 1954 and was reprinted in 1961 and 1982. After the establishment of the ELCT, the hymnal retained the same title. Nyimbo za Kikristo had 287 hymns and contained a Sunday service liturgy and the order of service for Holy Communion, baptisms, burials and weddings (Makanisa ya Kilutheri ya Tanganyika 1954). In 1988, the Nyimbo za Kikristo was succeeded by a new hymnal entitled Mwimbieni Bwana [Sing to the Lord]. This book had 382 hymns. The new additions in this hymnal were the special prayers and Bible verses for each Sunday in the year and antiphons reflecting the season of the church year. In the 2000 edition of Mwimbieni Bwana, some corrections were made to the previous edition. Three more hymns were added, making the total number of hymns 385 (Kanisa la Kiinjili la Kilutheri Tanzania 1988, 2000).

In 2012, the ELCT issued a new hymnal entitled Tumwabudu Mungu Wetu [Let Us Worship Our God], which is our main concern in this article. In the preface, the rationale for adoption of a new title is clarified - the title considers the fact that the worship service includes, in addition to hymns, for instance, confession, recitation of the creed, Holy Communion and baptism. It can be argued that the title denotes the gravity that the liturgical material and prayers are given in this hymnal. This hymnal has 440 hymns. In addition to the material already found in the preceding hymnals, Tumwabudu Mungu Wetu has a number of prayer alternatives for different occasions (Kanisa la Kiinjili la Kilutheri Tanzania 2012).

\section{The Evangelical Lutheran Church in Tanzania hymnal and praying for the departed}

The development of the ELCT hymnal followed an augmentation pattern. The increase in the number of hymns from different traditions, as well as the prayers, liturgies and so on, aimed at addressing a need to enrich the worship life of the parishioners. It should, however, be noted that even with this development, no single hymn in the ELCT hymnal can be considered explicitly a prayer for the departed. The few hymns that may be considered prayers for the departed are actually prayers for those who are dying or constitute a farewell to the departed. The ELCT hymnal contains hymns from various backgrounds and traditions, especially from Europe, the US and Africa. A large proportion of the hymns are translations of the German originals. It is worth noting here that hymns that address the departing, or are a farewell to the departed, are of Western origin, mainly from Germany, Great Britain or the US. The ELCT hymnal has seen an increase in hymns of African origin. However, none of these hymns intercedes for the dead.

At least four hymns in the hymnal address this topic. Hymn number 226 is Luise Hensel's evening hymn Müde bin ich, geh zur Ruh (Kanisa la Kiinjili la Kilutheri Tanzania 2012:173). The fourth stanza reads:

Calm those with problems, wipe away their tears

Receive all those who will die this night. (Kanisa la Kiinjili la Kilutheri Tanzania 2012:173, [transl. by Moshi])

Another example is hymn number 222 (Kanisa la Kiinjili la Kilutheri Tanzania 2012:170), Herr, es ist von meinem Leben, by Caspar Neumann. The fifth stanza of this hymn goes:

When day again dawns, I will wake up with zeal

To serve you earnestly in all spheres

If you will call me unto death this night

I surrender Lord my soul into your hands. (Kanisa la Kiinjili la Kilutheri Tanzania 2012:170, [transl. by Moshi])

As noted, what is then traceable in the ELCT hymns, in connection with the departed, are well wishes. Examples of such hymns include hymn number 207, by Sarah Doudney (Kanisa la Kiinjili la Kilutheri Tanzania 2012:157-158). The first and fourth stanzas read:

Sleep on, beloved, sleep, and take thy rest;

Lay down thy head upon the Saviour's breast;

We love thee well, but Jesus loves thee best -

Good night! Good night! Good night!

Until the Easter glory lights the skies,

Until the dead in Jesus shall arise,

And he shall come, but not in lowly guise -

Good night! Good night! Good night! (Kanisa la Kiinjili la Kilutheri Tanzania 2012:157-158, [transl. by Moshi])

Hymn number 201 reflects the same tone of farewell and encouragement in stanzas 2 and 3:

Jesus is a leader in the valley of death,

He has gone before you in the way of the grave and Paradise.

Jesus grant us to be where the conquerors are.

You are taken by the angels to the Lord.

You will be received by God's elect.

Jesus grant us to be where the conquerors are. (Kanisa la Kiinjili la Kilutheri Tanzania 2012:153, [transl. by Moshi]) 
These farewell words and wishes are also found in the funeral service liturgy in the hymnal. In one part of this liturgy, which addresses the departed, is a quotation from Psalms 121:8 (Kanisa la Kiinjili la Kilutheri Tanzania 2012:640), which reads: 'The Lord will watch over your coming and going both now and forever'. The hymns quoted above are translations from the German and British originals. In developing the hymnal, the ELCT seems to have subscribed to the traditions of the Lutheran missionaries, who did not introduce any prayers for the departed.

The hymns focus on the need to put trust and hope in the Lord, and they ask for the Lord's help for those with problems. Moreover, they signal a wish that the dead soul be taken to the Lord, but nonetheless they leave its destiny for the Lord to decide. In addition, the hymns adhere to a traditional view that when we die we 'go to sleep' and in due time 'shall arise in Jesus', as the hymn quoted previously indicates. This position and tradition was maintained when the ELCT incorporated hymns from African backgrounds. The African hymn composers have tended to respond to the expectation that the departed are not an object of prayer.

However, the question remains as to whether all or even a large proportion of the ELCT members subscribed to the position that it is un-Lutheran to pray for the departed. What if some sections of the church wanted hymns and prayers for their deceased beloved ones? These sections would then be left with only two alternatives. Either they would have to conduct such prayers secretly, and presumably grudgingly, or demand public conduction of such prayers because they too constitute a group of authentic members of the church.

The inclusion of prayers for the departed in the 2012 edition of its hymnal can be seen as an attempt to respond to the wishes of at least a part of its members. In an interview with Pastor Habakkuk Lwendo, who was a member of the ELCT hymnal committee, he alluded to the fact that some church members had actually been participating in prayers for the dead before the decision to include the prayers in the ELCT hymnal. The manner of their participation in these prayers varied. For instance, a bereaved clan might hold a traditional prayer for a dead relative, in which case participation would be demanded of every member of that clan or family. Lwendo also observed the fact that funerals and their associated practices, being collective events, resulted in the exposure of the ELCT members to something that was not part of their church tradition. In addition, funerals can reveal several traditional cultural practices, which may have been forgotten by some Lutherans. This exposure can thus have a twin effect on the people's underlying traditional culture and the surrounding denominations, such as the Roman Catholic Church (Habakkuk Lwendo [Tumaini University] pers. comm., 22 November 2017).

In an interview with ELCT, Pastor Seth Ole Sululu (21 November 2017), a church musician, pointed out a number of issues that have been considered to be push factors for the inclusion of the prayers. Some members of the ELCT requested or demanded the inclusion of prayers for the dead in the hymnal. This could be attributed to the exposure and practice of the prayers as explained above. Sululu also emphasised issues emanating from the ELCT hymnal itself (the present version as well as previous ones). Some members considered phrases like 'The Lord will watch over your coming and going both now and forever' not as a farewell to the departed during the funeral service but as talking to the dead. This, for some Lutherans, has opened avenues for inclusion of more prayers.

In response to the above, the ELCT structured seven prayer alternatives addressing the issue of the departed and included these in its hymnal. This is deemed to be the first time the ELCT embarked on such a venture. The first of the seven prayers (Kanisa la Kiinjili la Kilutheri Tanzania 2012:607) reads:

Lord Almighty our heavenly Father. We pray for the sake of your Son Jesus Christ, grant our departed relative your grace and everlasting peace. Be merciful to him/her and give him/her eternal life. Faithful Lord and Saviour Jesus Christ, guide the departed in the light of God and bring her/him to the communion of saints. Be merciful to us and guide us in righteousness so that our journey to you will be safe, so that we may celebrate the resurrection with the saints. (Kanisa la Kiinjili la Kilutheri Tanzania 2012:607, [transl. by Moshi])

This alternative prayer has been considered the one that is most un-Lutheran. What has been questioned is that God, in the prayer, is asked to give the departed relative eternal life. Moreover, the 'safe journey to God' has been viewed as crypto-Catholic, having too much resemblance with the idea of purgatory - suggesting that the departed ones are 'lingering somewhere' and need to be brought to safety. ${ }^{9}$ These reactions tally with notions in other conservative Lutheran circles, where it has been emphasised that we should pray 'for ourselves and for all other people, even for our enemies' but that we should not pray 'for the souls of the dead' (Lutheran Church Missouri Synod 1991:85). We may, however 'surrender them in prayer to God' (Gould 2016:50-51; Suomen evankelisluterilainen lähetyshiippakunta 2017:145). ${ }^{10}$

The rest of the prayers are milder and therefore considered more in line with remembrance - although many still do not regard them Lutheran. The prayers are presented in sequence below:

Great God, heavenly Father, our relative has left this life. We stand before you and the position our relative occupied is empty. We are filled with sorrow in our minds and hearts. But we depend on you knowing that we are in your fatherly care.

Father, you are greater than our sorrow, in you we have rest. We bring before you our past pains regarding our fear of death. We thank you for the years we spent with our relative and all that made him/her what he/she was amongst us.

9.This was pointed out by Elieshi Mungure (E. Mungure [LWF] pers. comm., 24 November 2017), but it was also pointed out by other theologians and lay members in several discussions after the publication of the hymnal in 2012.

10.This point - that we may surrender the souls of the deceased in prayer to God - is not to be found in the 1991 edition of An Explanation of the Small Catechism by the Missouri Synod, but in the Finnish translation of the Explanation this phrasing was added. 
May all the good things she/he did and stood for strengthen us. Help us to leave behind all that brought strife that it may not disturb and weaken our hearts and thoughts. In the midst of all that was tiring and inflicting pain, we thank you for all those who have been with us as we grieve the demise of our relative. Help us in our sorrow and in the plans ahead of us.

We lift our heart to you, Lord. Grant that your Son be our hope in life and death. Grant that we should always live under your guidance until heaven, where we shall, together with the elect praise our Saviour. Amen.

God our heavenly Father, as we leave the graveyard, life looks very different from the way it looks every day. Humanly, I cannot understand why things go this way on Earth. I find it difficult to understand fully, but I cannot avoid this situation. I need to learn that life on Earth is brief and has limits. For now, I need to be thankful even for that which goes against my thinking. Lord, I am part of that which does not endure on Earth. In this cemetery, help me to understand that life on Earth includes good health, sickness and death.

Jesus Christ, you came to the weak and doubtful. You have met fear and hopelessness. You conquered sin and death. By your resurrection, you have made the Earth a place where people can live and the church has the opportunity to thank you for the inexplicable gift of salvation. In you, life gets a new meaning and in faith I will transcend the limitations of time. That's when I, as a member of our church, will join the heavenly host to praise you.

O Lord, give me courage to attend worship services so that I may grow in faith. I thank you that though I am weak I can be your disciple doing your will in this world. This is the state in which I pray, being imperfect, but in faith. Amen.

Gracious Father, whose beloved Son Jesus, our Lord Christ, was resurrected, emerging conqueror over death and the grave, we thankfully remember your faithful people who depended on Christ, whose tears have gone by and their sorrow turned to joy; we humbly ask you to strengthen us in the certainty of the resurrection of the dead and the life in the world to come. In Jesus Christ our Lord. Amen.

Everlasting God, your love is more powerful than death and your suffering is greater than the grave. We celebrate the lives of those whom you have drawn into your bosom eternally. Guard us in their joyful fellowship till we join the saints from every tribe and nation in front of your throne in everlasting glory. For the sake of your Son, our Lord Jesus Christ. Amen.

We thank you, God, for your servants and witnesses in the past: for Abraham and Sarah, Moses and Miriam, Deborah and Gideon, Samuel and Hannah; for Mary, the mother of our Lord; for Mary Magdalene, Peter, Paul and for all apostles; for Stephen and Phoebe, and for the martyrs and all saints of all times and places. In your mercy, grant us, as you grant them, the hope of salvation and the promise of eternal life in Jesus Christ, our Saviour and Lord. Amen.

God, our heavenly Father, we owe you thanks for what has happened in the past. We thank you for your faithful people who in past generations stood for faith. Many gave their lives for the sake of the gospel. We thankfully remember today all those through whose strong faith in you, the Church still has strength for the good of the world.

We thus thank you, God Almighty, for all the saints. We ask that their good example inspire and awaken our hearts so that we may lead faithful lives in witnessing to Christ, our Redeemer. Amen. (Kanisa la Kiinjili la Kilutheri Tanzania 2012:607-608, [transl. by Moshi])

According to Pastor Elieshi Mungure, a former member of the ELCT theology and ethics committee, these prayers are meant as guides (E. Mungure [LWF] pers. comm., 24 November 2017). The idea behind them was in reality the priesthood of all believers, to make tools for worship, including prayers, accessible to every Christian and not only to pastors. Sometimes there may be a situation where a layperson needs to say a prayer on a specific issue, especially at an incident of sudden death. Thus, indeed, as the explanatory notes on the prayers indicate, the prayers could be said by, for instance, a relative or hospital worker (Kanisa la Kiinjili la Kilutheri Tanzania 2012:607). These prayers, therefore, were intended to constitute an aid both to pastors and to congregants in general. This consideration may be of value in our analysis of the hymnal. At the same time - given the importance that the hymnals have had as doctrinal documents in Lutheranism - we can understand that the critics in the ELCT saw the prayers for the departed as an unwelcome addition implying a deviation from 'proper' Lutheranism.

These are the prayers that have raised concern in the ELCT in general, culminating in the issues raised in the Dodoma pastors' assembly. Considering that the gist of preparing a new version of the hymnal was to enrich this tool of worship for the ELCT members, it can be argued that the 2012 hymnal was expected to be at least as 'Lutheran' as the previous editions. Given the negative reactions that the inclusion of the prayers caused, there may be a need to consider the issue more critically. The following sections attempt to address the issue of Lutheranism and praying for the dead.

\section{The Lutheran reformers and praying for the departed}

Praying for Christians who have left this life is not uncommon in the history of the Christian church. Christians were known to have prayed for the souls of the departed from at least the 3rd century AD. While it is difficult to assert anything as regards individual prayers for friends and relatives who had died, we know more about the collective prayers. Hamilton (1916:204-205) believes that communal praying by Christians for the faithful departed may have started at the end of the 2nd century. Around 303 AD, writes Hamilton (1916:207-208), we find the earliest reference to praying for the dead in an intercession in the ordinary worship. It should be noted that these early communal prayers were offered for the faithful departed and especially for martyrs, and not for departed ones in general (Hamilton 1916:204-205, 210). In the early intercession, the parish could, for instance, 'commemorate the holy martyrs, that we may be deemed worthy to be partakers of their contest' or 'pray for all those who have fallen asleep in their faith' (Hamilton 1916:210). 
The reformers did not seem to have a strong opinion about prayer for the dead but treated it in the same manner as other similar adiaphoric customs. In 1528, Martin Luther wrote the book Vom Abendmahl Christi, Bekenntnis (Confession Concerning Christ's Supper), where he writes as follows:

For the dead ones, while the Scriptures do not state anything about that, I am of the opinion that it is not a sin if, at a free devotion, one prays like this or similarly: 'Dear God, should the [person's] soul be in such shape that I could help, please be merciful to him' and so on. And when that has been done once or twice, let it be enough. Vigils, requiem masses and annual [commemoration] ceremonies are of no use and is the annual market of the devil. We also have nothing in the Scriptures about purgatory, and [it] is indeed also brought in by poltergeists; therefore, it is not to be believed. (Luther 1909 [1528]:508, [transl. by Groop])

While Luther rules out purgatory altogether, he asserts, at the same time, that everything is possible for God; thus, God could 'make the souls suffer after they have left [this] life' (Luther 1909 [1528]:508, transl. by Groop).

The reformers thus seem to show understanding for the old custom of praying for the dead. 'We know', writes Philipp Melanchthon (2004 [1531]):

that the ancients speak of prayer for the dead, which we do not prohibit but we disapprove of the application ex opera operato of the Lord's supper on behalf of the dead. (\$94)

It was a later custom of not only praying for the dead, or even to them, but offering them also Holy Communion, to which the reformers objected.

At the very centre of Luther's criticism of the Catholic Church was purgatory and, even more essential, the comprehension that the priests and ultimately the pope possessed the power to rescue people from this suffering. Those still alive were taught that that they could shorten their time in purgatory through monetary concessions to the church, for instance, through buying indulgences, after which the priest would make sure that the soul of the person took a shortcut through the burning fire. However, the Catholic priests could also help those who had already departed. This was done through a mass for the dead. Melanchthon (2004 [1531]) writes thus about this mass:

Our adversaries have no testimonies and no command from Scripture for defending the application of the ceremony for liberating the souls of the dead, although from this they derive infinite revenue. Nor, indeed, is it a light sin to establish such services in the Church without the command of God and without the example of Scripture, and to apply to the dead the Lord's Supper, which was instituted for commemoration and preaching among the living [for the purpose of strengthening the faith of those who use the ceremony]. This is to violate the Second Commandment, by abusing God's name. (\$89)

In this section, Melanchthon twice refers directly to the scriptures, and three times he indirectly does so by referring to God's command, to the institution of the Lord's Supper and to the second commandment. However, he also juxtaposes the Protestant 'insight' that the mass for the dead is theologically wrong against the fact that this mass was lucrative for the Catholic Church. According to Melanchthon (2004 [1531]), the major problem was connected with the concept of salvation through faith:

For, in the first place, it is a dishonour to the Gospel to hold that a ceremony ex opera operato, without faith, is a sacrifice reconciling God, and making satisfaction for sins. It is horrible saying to ascribe as much to the work of a priest as to the death of Christ. Again, sin and death cannot be overcome unless by faith in Christ, as Paul teaches, Rom. 5, 1: 'Being justified by faith, we have peace with God, and therefore the punishment of purgatory cannot be overcome by the application of the work of another'. (\$89)

Here Melanchthon adds to his image the Catholic business idea of the exaltation of the services of priests. Mass, according to Melanchthon, is not a satisfaction, but a promise and sacrament that requires faith. It 'does not make satisfaction for guilt', writes Melanchthon (in §90), 'otherwise the Mass would be equal to the death of Christ. Neither can the remission of guilt be received in any other way than by faith'.

We should keep in mind that Melanchthon writes of mass for dead people who were baptised into the Catholic Church and not for 'pagans'. The pagans were beyond reach - at least humanly speaking. Luther's and Melanchthon's criticism was aimed at a highly institutionalised internal custom through which Christians hoped to be able to assist the souls of their deceased Christian friends and relatives. Melanchthon tactically positions the scriptures against '[Pope] Gregory [I] or the moderns', who, he emphasises, 'were men, and could err and be deceived'. However, more importantly, he asserts (in §95) that if the fathers were to be alive again and could see how their words were being understood, they would 'interpret themselves [their own dictums] far differently'. The Catholic Church had developed a theology on purgatory and services, which found little acceptance among the reformers, but the custom of praying for and to dead Christians and saints was met with at least some measure of understanding.

\section{A comparison: Lutheran prayers for the departed in Finland and Sweden}

While the focus in this article is on the ELCT and its hymnal(s), it may be of interest to also look at practices in Lutheran churches in other contexts. In this section, we will focus on Finland and Sweden, where the majority of the population are members of the Lutheran Church. There are several examples in the practice of Lutheran churches in the two Nordic countries, where the dead are specifically commemorated as the subject of prayers. In most examples, the departed one is merely being remembered and entrusted to the love and mercy of God. However, as we will see, there are also examples of prayers where the congregants address the issue of eternal life more actively and beg God to give their dead friend or relative eternal life. 
In the Book of Worship in the Evangelical Lutheran Church of Finland there is a passage in one of the ordinary intercessory prayers where those who have died are being prayed for. One section of the prayer reads as follows:

We pray for those who experience life to be meaningless.

Remember those who suffer from loneliness and insecurity,

all sick and those who are close to death.

We pray for our dear ones who have left this life.

We are looking forward to the day

when we together with them and all saints

shall be surrounded by the brilliant light of your face.

We leave ourselves and our whole world in your hands. (Evangelisk-lutherska kyrkan i Finland 2000a:307, [transl. by Groop])

In the regular Sunday service, there is also a passage where those who have recently been baptised and have passed away are mentioned by name. The age of those who have died is also stated. After this, and when the pastor has prayed together with the congregation for the mourning relatives and friends, there is a short break, often followed by organ music, and then the service continues. The purpose of this break raises questions. While the pastor does not pray for those who have died, it could be argued that the break offers a good opportunity not only to pray for the friends and relatives of the deceased one, but also for and to the deceased individual.

In the Evangelical Lutheran Church of Finland, the evening worship on All Saints Day takes this one step further. All the names of those parish members who have passed away since the last All Saints Day are read aloud. This commemoration is then followed by this intercessory prayer:

God our father. We thank you for the people we remember tonight. We thank you for our dear ones with whom we were allowed to share joy and sorrow. In their hearts, there was room for us. Also free us from our selfishness and instil love in our hearts through your holy spirit. Make us sensitive so that we see the needs of our fellow human beings. Comfort all those who are in deep sorrow.

We thank you for all those who in life and in death trusted you and prayed for us. Their example draws us closer to you and strengthens us in anticipation of eternal life. Help us also, like them, to hold onto the word and the holy sacraments that you share with us in your church. You remove our burdens and prepare the way for the arrival of your kingdom.

Strengthen us in faith in the power of resurrection. Help us remember that death cannot forever separate us from our loved ones. We trust in the fulfilled work of Christ and await with hope and joy the day when we will finally come home to your heavenly kingdom. Let us all once meet in the jubilant assembly before your throne and see you face to face. (Evangelisk-lutherska kyrkan i Finland 2000a:266, [transl. by Groop])

In the prayers for the funeral service and other devotions after someone's death there are in general two foci in the prayers. One is the handing over of the dead person to God and giving thanks for his or her life, and the second is praying for the relatives and friends who are mourning (Evangelisklutherska kyrkan i Finland 2000c:69-70, 75, 79-80, 234-235). In one case, the prayer goes further and is more personal. This example is from the third part of the Church handbook, which deals with devotions:

God, dear Heavenly Father, it feels difficult for us to refrain from [name]. But we believe he/she has gone to the eternal rest, where he/she is now free from worries, sufferings and afflictions. Receive him/her. Comfort and strengthen us who remain, and help us to always trust in you and your mercy. Hear us for your Son, Jesus Christ. (Evangelisk-lutherska kyrkan i Finland 2000b:70, [transl. by Groop])

In the Church of Sweden there are similar sections in the Worship Book of 1986, used until 2018, where those who have recently died are mentioned or prayed for - in intercessory prayers within the Sunday service and when bidding farewell to a dear one who has died. In one of the regular intercessory prayers the text reads as follows:

Pastor: We pray for those

who have been taken away by death ...

Let your eternal light shine for them.

[chime]

We pray for those who mourn,

let them find comfort and rest in you.

Keep them in your love.

Parish: Lord, hear our prayer. (Svenska kyrkan 1986:127, [transl. by Groop])

In the same handbook, in the section 'Devotion by the coffin' the prayer reads:

O God, you know what fills our hearts when we are gathered around [name]. Thank you for everything you gave him/her during life. Thank you for the joy and love we received through [name]. In your love, we entrust [name] who passed away. Take $\mathrm{him} /$ her to you and give him/her life of your life. (Svenska kyrkan 1986:232, [transl. by Groop])

The Worship Book of the Church of Sweden, which had been in use since 1986, was replaced by a new one in 2018. In this Worship Book, there is only one phrasing where those who have died are prayed for within an ordinary Sunday service. This verse occurs in three different prayers and reads as follows:

God, your grace endures in life and death. We remember and thank you for [name/names] in our parish who was/were taken away by death (and whom we mention by name), [name] (at the age of) ...

[break]

God, we pray for all who mourn. Embrace them with your comfort. Let the eternal light shine for the living and the dead. Hear us, gentle God our Lord. (Svenska kyrkan 2018:77, 86, 89, [transl. by Groop])

In the section in the Church of Sweden Worship Book for the funeral service, there are several prayers where the parish thanks God for the person who has passed away and prays 
for those who are mourning. There are also three short prayer alternatives for the Christian who has passed away. One reads as follows:

You gave [name] life.

Receive him/her in your peace and give her/him through Jesus Christ a joyous resurrection. (Svenska kyrkan 2018:262, 276, [transl. by Groop])

The Worship Book also suggests two prayers to be read at the interment before the coffin is lowered into the grave, of which one is chosen:

Pastor: Give [name], O God/O Lord, your peace and let your eternal light shine for her/him.

Parish: Amen

Or

Pastor: Jesus Christ, you who are the resurrection and the life, give [name] your peace and let your eternal light shine for her/him.

Parish: Amen. (Svenska kyrkan 2018:268, 271, 280, 283, 314-315, [transl. by Groop])

In the section 'Funeral service for stillborn children or children who have died in their infancy', there is a prayer that does not occur in other settings in the Worship Book. The prayer is rather personal and reads as follows:

Pastor: God, we miss [name] so much.

Now it is empty and sad.

Why could not [name] live?

Your love is stronger than everything,

even stronger than death.

Therefore, we ask you to take care of [name].

In the name of Jesus.

Parish: Amen. (Svenska kyrkan 2018:275, 289, [transl. by Groop])

These examples illustrate how the dead are remembered in prayer and thanksgiving in the Worship Books of the Evangelical Lutheran Church of Finland and the Church of Sweden. While the focus in the prayers is on thanking God for the one who has left us, handing him or her over (unconditionally) to God and praying for the ones who are mourning, there are also examples of prayers for the person who has died.

It is noteworthy that the Church of Sweden, somewhat more than the Evangelical Lutheran Church of Finland, has prayers with a bright eternal life in mind or, put bluntly, prayers where the next of kin may feel that they can affect the outcome. In the Finnish Lutheran Book of Worship, the parish prays 'for our dear ones who left this life' and 'looks forward to' the day 'we shall be surrounded by the brilliant light of your face', not explicitly pointing at heaven but possibly at the day of judgement. In another prayer in the Lutheran Church in Finland, the parish 'believes' that the deceased person has been given eternal rest, and the parish asks God to 'receive him or her'. In the Church of Sweden, in the worship book of 1986, which was still used in 2018, there is a slightly more suggestive phrasing where those praying ask God to let his 'eternal light shine for' the one who has died. In another phrasing, the parish asks God to 'take him or her to $[$ him]' and to give the deceased one 'life of your life'. The new Swedish Lutheran Book of Worship has the most prayer alternatives and, furthermore, it opens up the possibility of affecting the afterlife of the deceased one through prayer. God is asked to 'take care of' the person who has died, he is asked to 'receive him or her into [his] peace', to 'give' the one who has died 'a joyous resurrection' and to let his 'eternal light shine' for the deceased (see preceding quotes).

It should be pointed out that the formulations mentioned do not necessarily imply that the ones praying wish to try to change the situation of the deceased but rather that they express trust in the mercy of God. Moreover, our intention is not to present any verdict regarding how Lutheran these variations are, but rather to demonstrate the fact that two old neighbouring Lutheran churches have interpreted Lutheran doctrines somewhat differently. Overall, these prayers for the dead are few and relatively little elaborated. Little attention is paid to details regarding the one who has passed away and his or her afterlife. This may tie in with the Lutheran conception that this is an adiaphoron and should not be given too much attention. The focus is almost entirely on God's grace, redemption through Christ and hope for eternal life, for both those Christians who are alive and those who have passed away.

\section{The prayers: A white elephant to whom?}

Let us return to the ELCT and make an attempt at a brief analysis of the ambivalence reflected in the inclusion of the prayers for the dead and the rather immediate call for their exclusion or editing. The majority of the ELCT members have tended to be against such prayers. To these Lutherans, praying for the departed not only takes us back to the practices before the 16th-century Reformation but also (as indicated by Ole Sululu, 21 November 2017) signals a return to the pre-Christian era in Africa and its veneration and worship of spirits. Alternatively, there are those who value these prayers and probably for them, if we are not to succumb to hypocrisy, we have to 'officiate' what has been going on 'in secret'. Thus, the ELCT, mindful of this apparently theologically 'disturbing' practice, responded to a felt need and included the prayers in its hymnal (Habakkuk Lwendo [Tumaini University] pers. comm., 22 November 2017). While the ELCT's efforts are commendable, what is at the core of the opposing quarters is worth analysing. Several factors may underlie the tension.

One of the factors is the heterogeneous ethnic composition of the ELCT. In Tanzania, there are cultures that honour the departed and cultures where ancestor veneration is not so developed. A survey of cultural practices between Bantus and Nilotics, for instance, reveals different trends. The Bantus 
are more likely to practise ancestral veneration than the Nilotics. Sululu, who is a Maasai Nilotic, pointed out that ancestral veneration is not practised by his people (Seth Ole Sululu [ELCT] pers. comm., 21 November 2017). Prayers for the departed may be more appealing to cultures that practice ancestral veneration than to those that do not. The cultural diversity manifest in Tanzania can, therefore, in part explain the tension within the ELCT as to whether the prayers should be incorporated in the hymnal or not.

It should also be noted that, in addition to differences between ethnic groups, there are variations within ethnic groups in Tanzania. That is to say, resistance to prayers for the departed may be observed even - and maybe most vehemently - from a quarter that traditionally practises ancestral veneration and vice versa. Then again, we also have to consider the differences in Lutheran Christian traditions. As mentioned, the ELCT is the result of a merger of seven Lutheran churches in Tanzania. This has led to variations in some practices and inclinations, as reflected in the episcopal traditions within the ELCT, and may have a bearing on the resistance to or acceptance of the prayers. Adding to these factors is the modifying effect of the different denominations and the changing landscape of religiosity in Tanzania. There are stark differences regarding prayers for and to the departed, for instance, between Catholics and Pentecostals. In addition, the revival movements have had an effect on the different mainstream denominations, which may be difficult to disentangle.

The last but not least of the factors has to do with the wording of the prayers. The subheading for the prayers in the 2012 ELCT hymnal (Kanisa la Kiinjili la Kilutheri Tanzania 2012:607) alludes to remembrance of the departed. The title for the prayers in discussion reads: Sala ya Kumbukumbu kwa Wapendwa Waliotutangulia [Prayers of remembrance for our beloved departed]. Prayers of remembrance, in this context, may be considered a milder phrasing than (simply) prayers. The wording thus does not signal any possibility to change the situation of those departed who - or whose friends and relatives - are being remembered in prayer. While the title of the prayers points to remembrance, the wording of the actual prayers suggests otherwise, as indicated previously. The title and the contents are therefore at variance. Many theologians, such as Elieshi Mungure, indicated that the prayers - at least the first of the alternatives presented here - needed editing. However, instead of amending the prayers the ELCT issued a new hymnal where the prayers had been removed altogether.

The reformers' writings may surely offer useful tools to tackle this delicate matter. Moreover, traditions in other Lutheran churches may provide a necessary comparison. The reformers did not explicitly forbid praying for the deceased, and there are indeed other Lutheran churches where this custom exists. The interesting question is how far an individual Lutheran church 'can allow' itself to take the matter of praying for the departed, given that this issue can, at best, be regarded as an adiaphoron. Although the ELCT has to address its needs in its own context and cannot be forced to buy wholesale the practices of others, it can have points of reference such as the wordings of the reformers and traditions of sister churches. Nonetheless, for the ELCT to find a solution that is widely accepted, it will also have to consider its various contexts thoroughly, encourage open discussion on the matter and above all give the process enough time. Lastly, the ELCT will also have to remember that this is not the first time it has dealt with tension. It successfully handled the contentious issue of women's ordination and survived the dividing forces of the episcopal tradition. Unity does not necessitate homogeneity.

\section{Acknowledgements Competing interests}

The authors declare that they have no financial or personal relationship(s) that may have inappropriately influenced them in writing this article.

\section{Authors' contributions}

N.M. and K.S.G. contributed on an equal basis to the research and writing process. N.M. focused somewhat more on Tanzania and K.S.G. on the Lutheran historical perspectives as well as on Finland and Sweden.

\section{References}

Bethel-Bielefeld Mission, 1927, Nyimbo za Kikristo [Christian Hymns], Vuga, Tanga.

Bethel Mission, [c. 1914], Nyimbo za Kikristo [Christian Hymns], Wuga Mission Posta, Wilhelmstal.

Bethel Mission, 1936, Nyimbo za Kikristo [Christian Hymns], Vuga, Tanga.

Brown, P., 2000, 'The decline of the empire of God: Amnesty, penance, and the afterlife from late antiquity to the middle ages', in C. Walker Bynum \& P. Freedman (eds.), Last things: Death and the apocalypse in the middle ages, pp. 41-59, University of Pennsylvania Press, Philadelphia, PA.

Dal Santo, M., 2011, 'The God-protected empire? Scepticism towards the cult of saints in early Byzantium', in P. Sarris, P. Booth \& M. Dal Santo (eds.), An age of saints in early Byzantium', in P. Sarris, P. Booth \& M. Dal Santo (eds.), An age of
saints? Power, conflict and dissent in early medieval Christianity, pp. 129-149, saints? Powe
Brill, Leiden.

Evangelische Missionsgesellschaft für Ostafrika [Evangelical Mission Society for East Africa], 1908, Kitabu cha Nyimbo [A Hymn book], Evangelical Mission Society for East Africa, Tanga.

Evangelisk-lutherska kyrkan i Finland [Evangelical-Lutheran Church of Finland], 2000a, Kyrkohandbok för den evangelisk-lutherska kyrkan i Finland, Gudstjänstboken [Worship book for the evangelical Lutheran Church of Finland, church handbook], viewed n.d., from http://kyrkohandboken.fi/gt/gtb.pdf

Evangelisk-lutherska kyrkan i Finland [Evangelical-Lutheran Church of Finland], 2000b, Kyrkohandbok för den evangelisk-lutherska kyrkan i Finland, Handbok för kyrkliga förrättningar, Andakter vid olika tillfällen [Worship book for the kyrkliga förrättningar, Andakter vid olika tillfällen [Worship book for the
evangelical Lutheran Church of Finland, handbook for church services, devotions evangelical Lutheran Church of Finland, handbook for church services, devotions
on different occasions], viewed n.d., from http://kyrkohandboken.fi/forr/ forrattn_3.pdf

Evangelisk-lutherska kyrkan i Finland [Evangelical-Lutheran Church of Finland], 2000c, Del 1 Kasualhandlingar och andakter [Causal events and devotions], viewed n.d., from http://kyrkohandboken.fi/forr/forrattn_1.pdf

Gould, J.B., 2016, Understanding Prayer for the Dead: Its foundation in history and logic, Cascade Books, Eugene, OR.

Hamilton, G.F., 1916, 'Prayers of the ancient church for the faithful departed', The Irish Church Quarterly 9(35), 201-221. https://doi.org/10.2307/30067646

Heidemann, G., 2011, 'Relics and texts: Hagiography and authority in ninth-century Francia', in P. Sarris, P. Booth \& M. Dal Santo (eds.), An age of saints? Power, conflict and dissent in early medieval Christianity, pp. 187-204, Brill, Leiden.

Kanisa la Kiinjili la Kilutheri Tanzania [Evangelical Lutheran Church of Tanzania], 1988, Mwimbieni Bwana [Sing to the Lord], Evangelical Lutheran Church of Tanzania, Arusha.

Kanisa la Kiinjili la Kilutheri Tanzania [Evangelical Lutheran Church of Tanzania], 2000, Mwimbieni Bwana [Sing to the Lord], Evangelical Lutheran Church of Tanzania, Arusha. 
Kanisa la Kiinjili la Kilutheri Tanzania [Evangelical Lutheran Church of Tanzania], 2012, Tumwabudu Mungu Wetu [We worship our Lord], Evangelical Lutheran Church of Tanzania, Arusha.

Luther, M., 1909 [1528], 'Vom Abendmahl Christi, Bekenntnis' [Confession concerning Christ's supper]', in Dr. Martin Luthers Werke, Kritische Gesamtausgabe [Dr. Martin Luther's works, critical complete edition], 26 Band, pp. 241-509, Herman Böhlaus Nachfolger, Weimar.

Lutheran Church Missouri Synod, 1991, An Explanation of the Small Catechism Concordia Publishing House, St. Louis, MO.

Makanisa ya Kilutheri ya Tanganyika [Lutheran Church of Tanganyika], 1954, Nyimbo za Kikristo, Vuga Mission Press, Lushoto.

Melanchthon, P., 2004 [1531], Apology of the Augsburg confession, transl. F. Bente \& W.H.T. Dau, Concordia Theological Seminary, Fort Wayne.

Menzel, G., 1986, Die Bethel-Mission - Aus 100 Jahren Missionsgeschichte [The Bethe mission - From 100 years of mission history], Verlag des Erziehungsvereins $\mathrm{GmbH}$ Neukirchen-Vluyn.

Smedjebacka, H., 1973, Lutheran Church Autonomy in Northern Tanzania 1940-1963, Åbo Akademi, Åbo.
Spillett, R., 'Cambridge prepares for funeral of Stephen Hawking today with the wellknown atheist being remembered at a church service before his ashes are interred in Westminster Abbey', Daily Mail, 31 March 2018, viewed 14 January 2019, from http://www.dailymail.co.uk/news/article-5562129/Cambridge-prepareshttp://www.dailymail.co.uk/news
emotional-funeral-Stephen-Hawking

Suomen evankelisluterilainen lähetyshiippakunta [The Evangelical Lutheran Mission Diocese of Finland], 2017, Katekismus - Martti Lutherin Vähä katekismus lyhyest selitettynä [A short explanation of Martin Luther's small catechism], Suomen evankelisluterilainen lähetyshiippakunta, Porvoo.

Svenska kyrkan [Church of Sweden], 1986, Den svenska kyrkohandboken [The Swedish worship book], Svenska kyrkan, Uppsala.

Svenska kyrkan [Church of Sweden], 2018, Kyrkohandbok för Svenska kyrkan Del [Worship book for the Church of Sweden Part I], Svenska kyrkan, Uppsala, viewed 14 January 2019, from https://www.svenskakyrkan.se/default.aspx?id= 1735560

Von Sicard, S., 1970, The Lutheran Church on the Coast of Tanzania 1887-1914: With special reference to the Evangelical Lutheran Church in Tanzania, Synod of Uzaramo-Uluguru, Almqvist \& Wiksell, Uppsala. 